\title{
Parasitoid Insects of Agromyza Fallen (Diptera :Agromyzidae) of Iraq
}

\author{
Hanaa Hani Al Saffar* \\ Iraq Natural History Research Center and Museum, Baghdad University, Iraq \\ *Corresponding author
}

\begin{tabular}{|c|c|}
\hline & A B S T R A C T \\
\hline Keywords & \multirow{4}{*}{$\begin{array}{l}\text { The aim of this study to survey hymenopterous parasitoids on leafminer } \\
\text { Agromyza Fallen in Iraq. The survey was showed five species belonging to } \\
\text { five genera under three families, the parasitoids are : Digylphus isaea } \\
\text { (Walker) Pediobius metallicus (Nees), Cirrospilus vittatus Walker, } \\
\text { Halticoptera circulus (Walker), Opius sp. }\end{array}$} \\
\hline $\begin{array}{l}\text { Agromyza, } \\
\text { Agromyzidae, } \\
\text { Hynenoptera, } \\
\text { Parasitoids }\end{array}$ & \\
\hline Article Info & \\
\hline $\begin{array}{l}\text { Accepted: } \\
\text { 18 April } 2016 \\
\text { Available Online: } \\
10 \text { May } 2016\end{array}$ & \\
\hline
\end{tabular}

\section{Introduction}

Agromyza is a large genus occurs predominantly in temperate areas of the northern hemisphere and consist of more than 150 species are known throughout the world,(Spencer,1983). 99 of them in the Palaearctic region (Martines, 2004), cites the presence of 72 species in Southwestern Europe, and 43 in continental Spine (Ortiz, 2009). Many of them are economically important pests of the field crops, ornamental vegetables throw out the world (Spencer, 1973, 1990).

Species of Agromyza can be recognized by their unique mine patterns on plant leaves. These pattern could lead to the isolation of populations of parasitoids, especially if the pattern are used in host recognition. The shapes of the mine are correlated with rates of parasitism (Specer, 1973; Parkman et al.,1989).

Based on host-plants of Agromyza is divided into 4 groups: the nigripes group feeding on Graminae; the potentillae group mainly on Rosaceae but also on Betulaceae, Geraniaceae, Polygonaceae and Salicaceae; the rufipes group feeding on Boraginaceae, Compositae, Urticaceae, and other groups associated with Leguminosae (Spencer, 1976). The vast majority of species with host-plants are known as leafminers, but may also be stem-miners or gall-causers. Most larvae form blotch mines or wide linear mines after reaching their third instar. Pupation always occurs outside of the mine, usually in the soil. However, in swamp areas puparia glued on their host plant surface can 
be observed frequently (Dempewolf, 2004).

Agromyza species belonging to subfamily Agromyzinae and diagnosed with thes characters : sub-costa well developed and joining $R l$ before reaching costa; either $3+1$ strong dorso-centrals or 3 or more postsutural $d c$, greatly decreasing in size, with any presutural small and weak; orbital setulae reclinate; pre-scutellars present; second cross-vein normally present, discal cell large; stout species, wing length ranges from $1.45-3.5 \mathrm{~mm}$; most species entirely dark but a number with frons reddish or yellow; halteres also white or yellow; stridulating mechanism present in both sexes (Spencer, 1972, 1976 ).

Parasitoid assemblages of dipteran leafminers are dominated by Eulophidae, Braconidae and Pteromalidae that attack the larval and pupal stages of the flies. Overall, data from agricultural ecosystems suggest that agromyzid leafminers are attacked by a diverse assemblage of hymenopteran parasitoids that often are responsible for significant levels of leaf miner mortality (Gratton and Welter, 2001). Parasitoids also have been used successfully to control leafminer infestations in greenhouses (Minkenberg and Van Lenteren, 1986).

The number of parasitoids of leafminers have been recorded throughout the world (Neder de Roman and Arch de Hamity, 1985; Schuster, 1993; Shepard et al., 1998; Heimpel and Meloche, 2001; Cikman, 2006). The species of Braconidae are endoand ectoparasitoids on the egg and larval hosts, whereas those of Eulophidae are solitary or gregarious ectoparasitoids on larval and pupal hosts.

The parasitoids of Agromyza spp. were studied in several countries of the world,(AlAzawi, 1967, 1971; Gates et al, 2002;
Cikman and Uygun (2003); Gencer, 2000); Cikman, 2006; Sha et al, 2007; Cikman and Salle, 2011; Yeferemove et al,2011; Cikman 2012.

\section{Materials and Methods}

The survey of parasitoids of leaf miners were carried out during February March, April, May and October 2015, from several provinces of Iraq (Baghdad, Kerbala, Nejef, Diywaniya, Kut, Dhyla. Basra and THi Qar.

The infested leaves of different host plants: Medicago sativa, Trigonella phoenum, Melilotes indecus, Hordeum vulgare and different kinds of Weeds and Compositae plants, were collected and brought to the laboratory of entomology and put in Petri Dishes covered with filter paper under constant conditions. Temperatures $25 \mathrm{C}^{\circ} \pm 1$ and relative humidity 5\%. After that parasitoids were impressed from field sample and kept in small capsule.

The Agromyza spp. were identified using external morphology and male aedegous, (Spencer, 1972), the parasitoids identified by Prof. M.S. Abdul Rassoul and according to the reliable keys of (Chao-Dong,. and DaWei, 2001; Gates et al, 2002; Yefremova et al., 2011). All specimens are deposited at Department of Entomology at Iraq Natural History Research Center and Museum.

The infested leaves of different host plants: Medicago sativa, Trigonella phoenum, Melilotes indecus, Hordeum vulgare and different kinds of Weeds and Compositae plants.

\section{Results and Discussion}

In this study five hymenopterous parasitoids species attacking Agromyza spp. belonging 
to five genera under three families, Eulophidae, Braconidae and Pteromalidae, were collected from different region of Iraq. The list of species is given below:

Order: Hymenoptera (Linneus, 1758)

Family: Eulophidae (West wood, 1829)

1. Genus: Cirrospillus Westwood, 1832

Cirrospillus vittatus Walker, 1838

Material examined: It was found in Nejf on Agromyza albipennis on Hordeum vulgare 17.4.2015(2우. 1§). At Kut from A. nigripes on capscum, Cucumis and Lycopersicon in plastic houses (10 9 ,, 4 ते $\widehat{\jmath})$.2.5.2015

This species has been previously recorded as Cirrospillus sp. Hyperparasites of Lepidoptera pupae through its primary braconid and ichneumond hosts: Baghdad April (Al Ali,1977) recorded on Phytomyza horticola ( Mechlif and AbdulRassoul,2002; Abdul Rassoul and Al Saffar, 2014 on L. bryioniea on Trigonella Phoenum ).

Hosts: Liriomysa spp. (Cabello et al., 1994 C.horiticola, Cikman and Uygun, 2003).

General Distribution: Cosmopolitan species, Europe, Asia, North Africa, Canada,USA (Hansson,1985).

\section{2..Genus : Diglyphus Walker, 1844}

D. isaea (Walker, 1838).

Material examined: $D$. isaea was found in Baghdad from Agromyza nana Maigen on Melilotus indeca on 14.2. 2015 (10 우, 6 ऽิ đ); Kerbala, Agromyza albipennis Medicago sativa on 20 4. 2015(15우, 10 ○ð) in Nejef Agromyza sp. on Cucuribta sativa (20.5 2015.

(Notes: many specimens were brought from other provinces announced at material and methods).

This species has been previously recorded from Phytomyza horticola (Mekhlif and Abdul Rssoul, 2002) collected from different host plantsand from Liriomyza sativa, L.cogesta from various plants, (Abdul Rssoul and Al-Saffar, 2014).

Hosts: Many species of Agromyzidae and also Lyonetidae; Tephritidae and (Lepidoptera) (Zhu,et al 2000).

General Distribution: Widely Separated in Palearctic region and also Afrotropical, Australian, Pacific, Nearctic andOriental region (Boucek, 1965).

\section{Genus: Pediobius Walker, 1846}

Pediobius metalicus (Nees, 1834)

Material examined: It was found in Baghdad on Agromyza sp. on graminae weeds at 21.3. 2015 (.4우, 1ठ).

This species has been previously recorded as endoparasitoid from Melanogromyza phaseoli (Tryon) (Diptera : Agromyzidae) from gold stem of Dolchos sesiquipedalis (Abdul-Rassoul, 1976) endoparasitoid on Phytomyza atricornis from Baghdad Jan. and Feb. 1970 (Al- Ali, 1977) and on Phytomyza horticola ( Mekhlif and AbdulRassoul, 2002).

Hosts: Primary sometimes secondary, solitary endoparasites of larveae and pupae of mining forms of Lepidopytera and Diptera, Particulary agromyzids genera Phytomyza, Liriomyza, and Dizgomyza (Boucek, 1965 Boucek and Askew,1968). 
General Distribution: Europ, Asia, North America (Civelek and Oder, 1999).

Family:Pteromalidae Daiman, 1820

Genus :Halticoptera Spinola, 1811

Halticoptera circulus (Walker, 1833)

Material examined: It was found on Agromyza nana and A, albippenis on Trigonella Phoenum in 21.3.2015,from Baghdad, ( 4ㅇ, ㅇ ).

This species has been previously recorded as Halticoptera sp, Baghdad on Ternip 26.3. 1970. ( El- Haidari et al.), on, Phytomyza atricornis (Al Ali, 1977), on Phytomyza horticola (Mekhlif and Abdul Rassoul,2002).

Hosts: several genera of Agromyzidae (Peck, 1963; Lopes et al, 2004 ;Noyes, 2005).

General Distribution: Cosmopolitan species, Europe, Asia, North Africa, Canada,USA (Hansson,1985).

Family: Braconidae Nees, 1812

Genus: Opius Wesmael, 1835

Opius sp.

Material examined : Three samples were collected from Agromyza megalopsis on Compositae weeds

\section{References}

Abdul Rassoul, M. S. 1976. List of some Iraqi parasitic Hymenoptera. Bull. Nat. Hist. Res. Center, 7 (1): 138-141.

Abdul Rassoul, M. S and Al Saffar, H.H.
2014. Parasitoid of the genus Liriomyza Mik. in Iraq.. Int.J.Curr. Microbiol.App.Sci., 3(5): 618-624.

Al Ali, A. S. 1977. Phytophagous and entomophagous insects and mites of Iraq. Nat. Hist Res. Center, Publ. No.33, 142pp.

Al- Azawi, A. F. 1967. Agromyzid Leaf miners and their parasitites in Iraq. Bull. Entomol. Res., 57(2) : 285287.

Al- Azawi, A. F. 1971. Parasites of agromyzid leafminers in Iraq. Bull.Iraq nat.Hist. Mus., 5(1) :3537.

Boucek, Z. 1965. Studies of European Eulophidae IV. Pediobius Walk., and two alled genera (Hymenoptera). Acta Ent. Mus. Nat. Prague, 36:5-90.

Cabello, T. Jaimez, R. and Pascua, F. 1994. Sptial and temporal distribution of Liriomyza spp. and their parasitoidon horticultural crops in green house of southern Spain (Diptera: Agromyzidae). Bolrtin de Sanidad Vegetal Plagas. 20:445- 455.

Chao-Dong, Z. and Da-Wei, H. 2001. A taxonomic study of Eulophidae from Zhejiang, China (Hymenoptera: Chalcidoidoidea).Acta ootaxonomica sinica, 26(4): 533-547

Cikman, E. 2006.Parasitoid of the leaf miners (Diptera: Agromyzidae) from Aiyaman province. Turk. Entomol. Derg., 30(2):99-111.

Cikman, E. 2012. Parasitoids of the leafminers (Diptera: Agromyzidae) from Elaz Province, Turkey. Afr. J. Agric. Res..7(12): 1937-1943.

Cikman, E. and Salle, J. 2011. Parasitoid of leafminers (Diptera:Agromyzidae) in Malatya, Turkey. Türk. Entomol. Derg., 35(3) :475-484.

Cikman, E. and Uygun, N. 2003. The determination of leafminers (Diptera: Agromyzidae)and their 
parasitodsin cultivated and noncultivated areas in Sanliurfa province, Southern, Turkey. Tutk. J. Entomol., 27:305- 318

Cikman, E. Beyarslan, A. and Civelek, H. S. 2006. Parasitoids of leafminers (Diptera: Agromyzidae) from Southeast Turkey with 3 new. records.Turk. J. Zool., 30: 167-173.

Civelek, H. and Oder, F. 1999. Infestigation on determining of natural enemies of leafminers (Diptera : Agromyzidae) in Izmir province. Proceedings of the 4th Turkish Biological Control Congress, Adana, Turkey), 527- 540.

Dempewolf, M. 2004. Arthropods of economic importance: Agromyzidae of the World. Wokingham UK, ETI Information Services, unpaginated.

El- Haidari, H. Fattah, Y. M. and Sultan, J. A. 1971. Contribution to the fauna of Iraq. Director General of plant protection Bulletin, No.9, $20 \mathrm{Pp}$.

Gates, M. W. Hearaty, J. M. Schauff,M.E. Wagner, D. L. Whitfield, J.B. and Wahl, D. B. 2002. Survey of the parasitic Hymenoptera on leafminers in California. J. HYM.RES., 11(2): 213-270.

Gencer, L. 2004. A study of the Chalcidoid (Hymenoptera: Chalcidoea) parasitoids of leafminers (Diptera: Agromyzida) in Ankara province. Turk, J. Zool., 28: 119- 122

Ghahari, H. and Yefremova, Z. A. Hansson, C. 1985. Taxonomy and biology of the Palaerctic species of Chrysocharis Forster, 1856 (Hymenoptera: Eulophidae)Entomolo gica Scandnavia (Supplement). 26:p.43.

Ghahari, H. and Yefremova, Z. A. 2013. A study of the family Eulophidae (Hymenoptera : Chalcidoidea) from Iran. Zoosystematica Rossica,
22(2):303-210

Gratton, C and Welter, S.C. 2001. Prasitisim of natural populations of Liriomyza helianthi Spencer and Calycomyza platyptera (Thomson) (Diptera: Agromyzidae). Biological Control, 22: 81-97.

Hansson, C. 1985. Taxonomy and biology of the Palaerctic species of Chrysocharis Forster, 1856 (Hymenoptera:Eulophidae)Entomolog ica Scandnavia (Supplement). 26:p.43.

Hansson, C. 1995. Revision of the Nearctic species of Neochrysocharis Kurdjumov (Hymenoptera : Eulophidae). Entomologica Scandnavia, 26:27-46.

Heimpel, G.E. and Meloche, F. 2001. Biological control of alfalfa blotch leafminer (Diptera: Agromyzidae) in Ontario: status and ecology of parasitoid (Hymenoptera: Braconidae, Eulophidae) 20 years after introduction. Great Lakes Entomologist, 34: 17-26.

Lopes, E.D. F. Kafel, L. Lai, R. Y. and Chang, Y. F. 2004. Parasitism of Halticoptera circulus (Walker) (Hymenoptera: Pteromalidae) : A parasitoid of the Liriomyza trifolii ( Burgess) (Diptera: Agromyzidae) at different dencities. International Symposion on Tropical Agriculture ang Agro-biotechnology, Des.7-9.

Martines, M. 2004. Fauna Europaea: Agromyzidae. Fauna Europaea version 1.2 , http://www.faunaeua.org.html

Mekhlif, A. F. and Abdul Rassoul, M. S.2002. Efficiency of parasitoid pea leafminer Phytomyza horticola Goureau and their appearance time in the field. Bull. Iraq Nat. Hist. Mus., 9(4):27-32.

Minkenberg, O. P. J. M and van Lenteren, J. C 1986. The leafminers Liriomyza 
bryoniae and L. trifolii (Diptera:Agomyzidae) their parasites and hosts plants a review. Agricultural University Wageningen Papers, 86: 149.

Neder de Roman, L.E. and Arch de Hamity, M.G. 1985. Parasitoids of Liriomyza huidobrensis in the Quebrada de Humahuaca (Jujuy). Neotropica, 31: 181-186.

Noyes, J. S. 2005. Universal Chalcicoidea database. http://www.nhm/ chalcidoids.

Ortiz, R. G.2009. Biosystematics contribution to Agromyzidae (Diptera). Thesis Doctoral. University of Politecnica, 422pp.

Parkman, P. Dusky, JA. and Waddill, VH. 1989. Leafminer and leafminer parasitoid incidences on selected weeds in south Florida. Fla. Entomol., 72(3): :559- 561.

Sha, Z. L. Zhu, C. D. Murphy, R. W. and Huang, D.-W. 2007. Diglyphus isaea (Hymenoptera:Eulophidae)a problem complex of cryptic species that forms an important biological control agent of agromyzid leaf miners. J. Zool. Evol. Res., 45(2):128-135.

Schuster, D.J. 1993. Hymenopterous parasitoids of leaf-mining Liriomyza spp. (Diptera: Agromyzidae) on tomato in Florida. Environ. Entomol., 22: 1188-1191.

Shepard, B., Samsudin, M. and Braun, A.R. 1998. Seasonal incidence of
Liriomyza huidobrensis (Diptera: Agromyzidae) and its parasitoids on vegetables in Indonesia. Int. J. Pest Manage., 44: 43-47.

Spencer, K. A. 1972. Diptera Agromyzidae. In: Handbook for the identification of British insects, 10, part 5(g): 1-136.

Spencer, K. A. 1973. Agromyzidae (Diptera) of economic important.Dr. W. Junk.series Entomologica, Vol.9B.V. Publisher The Huge 414Pp. Spencer, K. A. $1976 . \quad$ The Agromyzidae (Diptera) of Fennonscandia and Denmark. In: Fauna Entomologica Scandinavian, 5/1: 1-304.

Spencer, K. A. 1983. Leaf mining Agromyzidae (Diptera) in Costa Rica. Rev. Biol. Trop., 31(1): 41-67.

Spencer, K. A. 1990. Host specialization in the World Agromyzidae (Diptera). Kluver Academic Publishers, Nedherland, 444Pp.

Yefremova, Z, Civelek, H. S. Boyadzhiyev, P. Dursun, O. Eskin, A. 2011. A review of Turkish Diglyphus Walker (Hymenoptera: Eulophidae), with description of a new species. Ann. Soc. Entomol. Fr.(n.s.), 47(3-4):273-269\.

Zhu, C. D, La Salle, J. and Huang, D.W. 2000. A review of Chinese Diglyphus Walker (Hymenoptera: Eulophidae) Oriental insects, 34:263-288.

\section{How to cite this article:}

Hanaa Hani Al Saffar. 2016. Parasitoid Insects of Agromyza Fallen (Diptera :Agromyzidae) of Iraq. Int.J.Curr.Microbiol.App.Sci. 5(5): 742-747.

doi: http://dx.doi.org/10.20546/ijcmas.2016.505.075 